\title{
Review of the fossil record of the Australian land snail genus Bothriembryon Pilsbry, 1894 (Mollusca: Gastropoda: Bothriembryontidae): new distributional and geological data
}

\author{
Corey S. Whisson ${ }^{1,2^{*}}$ and Helen E. Ryan ${ }^{3}$ \\ 1 Department of Aquatic Zoology, Western Australian Museum, Locked Bag 49, Welshpool DC, \\ Western Australia 6986, Australia. \\ ${ }^{2}$ School of Veterinary and Life Sciences, Murdoch University, Murdoch, Western Australia 6150, \\ Australia. \\ ${ }^{3}$ Department of Earth and Planetary Sciences, Western Australian Museum, Locked Bag 49, \\ Welshpool DC, Western Australia 6986, Australia. \\ * Corresponding author: corey.whisson@museum.wa.gov.au
}

\begin{abstract}
The land snail genus Bothriembryon Pilsbry, 1894, endemic to southern Australia, contains seven fossil and 39 extant species, and forms part of the Gondwanan family Bothriembryontidae. Little published data on the geographical distribution of fossil Bothriembryon exists. In this study, fossil and modern data of Bothriembryon from nine Australian museums and institutes were mapped for the first time. The fossil Bothriembryon collection in the Western Australian Museum was curated to current taxonomy. Using this data set, the geological age of fossil and extant species was documented. Twenty two extant Bothriembryon species were identified in the fossil collection, with 15 of these species having a published fossil record for the first time. Several fossil and extant species had range extensions. The geological age span of Bothriembryon was determined as a minimum of Late Oligocene to recent, with extant endemic Western Australian Bothriembryon species determined as younger, traced to Pleistocene age. Extant Bothriembryon species from the Nullarbor region were older, dated Late Pliocene to Early Pleistocene. Cave environments proved an excellent source of fossil Bothriembryon material, where shells often showed signs of predation. The dataset from this study provided insights into the origin and radiation of Bothriembryon, and will enable future phylogenetic dating.
\end{abstract}

KEYWORDS: Gondwana, Orthalicoidea, aridification, extinction, Western Australia

\section{INTRODUCTION}

Molluscs are important in understanding changes in biodiversity over time due to the high preservation rate of their hard calcareous shells and consequently long fossil record, compared to other invertebrates (Jell and Darragh 1998). But not all fossils are preserved and/or collected, and as such the global fossil record is imperfect (Behrensmeyer et al. 1992; Harper and Brenchley 1998). Fossilised molluscs not only provide information on the geological past through shell dating methods such as Uranium-series or Radiocarbon dating, but can provide past information on the ecology (e.g. predation = praedichnia), morphology (e.g. morphological stasis) and evolution of a group (Peppe and Deino 2013). While the use of molluscs for palaeoecological studies is on the rise, taxonomy has become less recognised, despite being inextricably intertwined with it (Forey et al. 2004).

In Australia, most molluscan fossils are of marine origin, with the terrestrial and freshwater component relatively sparse (Jell and Darragh 1998; Smith and Stanisic 1998). This is not unexpected as terrestrial mollusc deposits are less common in the southern hemisphere (Smith and Stanisic 1998) possibly due to high erosion via physical, chemical and particularly biological processes (Behrensmeyer et al. 1992). Environmental conditions in inland Australia during the Tertiary were generally poor for preserving fossils and hence few faunal deposits are known from this time period (Breed and Ford 2007). Bishop (1981) remarked that few Australian land snail fossils are known and the 
prospect of discovering more are not good, indicating this is a preservational bias rather than a sampling bias. Despite this, large fossil mollusc collections remain unstudied in most Australian museums and universities (Jell and Darragh 1998). This includes fossil material of the endemic land snail genus Bothriembryon Pilsbry, 1894, a member of the Gondwanan family Bothriembryontidae containing seven fossil and at least 39 extant species (Breure and Ablett 2012; Breure and Whisson 2012; Schneider and Morrison 2018; Stanisic et al. 2018).

\section{TAXONOMIC HISTORY OF FOSSIL BOTHRIEMBRYON PILSBRY, 1894 SPECIES}

The first described fossil species of Bothriembryon Pilsbry, 1894 was Bulinus gunnii Sowerby in Strzelecki, 1845 from south-east Tasmania, later clarified as genus Bulimus (misspelt) and distinct from the extant Bothriembryon tasmanicus (Pfeiffer, 1853) (Kershaw 1981). Similar to the extant fauna (Breure and Whisson 2012), fossil Bothriembryon have received little to no recent taxonomic attention, with only six additional species described from the fossil record in over 170 years since Bothriembryon gunnii was first discovered in Tasmania. Five of these species were from south-western Western Australia (SWWA): $B$. consors Kendrick, 1978 and B. gardneri Kendrick, 1978 from Windy Harbour; B. douglasi Kendrick, 1978 and B. ridei Kendrick, 1978 from Shark Bay; $B$. kremnobates Kendrick, 2005 from the Roe Plains. The remaining species, B. praecursor McMichael, 1968 was described from central Australia, being later revised by Ludbrook (1980). McNamara et al. (1991) listed Western Australian Museum type material and Richardson (1995) treated described fossil species. Later Breure and Whisson (2012) illustrated all fossil species, some for the first time, and listed type material.

\section{GEOLOGICAL AGE}

According to available literature, the oldest geological age of Bothriembryon has been determined as minimum Late Oligocene (Kershaw 1981) or broadly Tertiary (McMichael and Iredale 1959; McMichael 1968), based on the stratigraphy at the Tasmanian type locality of B. gunnii (Kershaw 1981). Similarly, stratigraphy at the Northern Territory type locality of B. praecursor has been dated as broadly Tertiary (McMichael 1968; Ludbrook 1980). Additional material of this species from South Australia narrowed the geological age to tentatively Miocene (Ludbrook 1963) or middle Miocene (Ludbrook 1980). Based on B. praecursor material, Kendrick and Wilson (1975) summarised the oldest age of Bothriembryon as tentatively Miocene, whilst Solem (1998) interpreted it as late Tertiary, but remarked that more records were needed to accurately determine the age of the Bothriembryon group. Kendrick (2005) suggested the age of B. praecursor needs clarification.
Based on unknown fossil specimens, Zilch (1959) tentatively placed the oldest age of Bothriembryon as Pliocene. Kershaw (1981) discussed an early Miocene age for the whole group.

\section{FOSSIL DISTRIBUTION}

Considering only type material, a total of just 41 lots, which are all holotypes and paratypes (note: $B$. gardneri erroneously listed as syntypes in Breure and Whisson 2012), the fossil distribution of Bothriembryon is restricted to the seven type localities around Australia (Breure and Whisson 2012) or in some cases, also in close proximity to them.

Available literature enhances this geographical distribution. In northern Western Australia (WA), an interesting record from the coastal part of Cape Range extends the known distribution much further north (Slack-Smith 1993). Kendrick and Wilson (1975) documented B. costulatus (Lamarck, 1822) from the mainland as well as insular Shark Bay, with B. onslowi (Cox, 1864) restricted to the mainland. Wilson (2008) later found fossil shells of $B$. onslowi from Faure Island in Shark Bay. Other Bothriembryon specimens have been analysed for dating at Shark Bay (Hearty 2003). Whisson and Kirkendale (2017) identified Holocene $B$. whitleyi Iredale, 1939 from the Geraldton area.

In south-east WA and eastward, fossil B. barretti Iredale, 1930 specimens were noted from the Roe Calcarenite and Bridgewater formations (Ludbrook 1978), with a very similar specimen noted from St Francis Island in South Australia (Kershaw 1985, 1986). This latter record extends the mainland distribution eastward significantly and offshore. A fossil record was documented from the Kent Group to the north of Tasmania (Kershaw 1981).

In lower SWWA, subfossils of B. rhodostomus (Gray, 1834) (tentative identification) were recorded from near Esperance, apparently exposed in large numbers (Cram 2010). Kendrick and Wilson (1975) recorded B. melo (Quoy and Gaimard, 1832) at Bremer Bay and Limestone Head. On the Leeuwin-Naturaliste Ridge, unidentified fossils were noted from soil pockets at Hamelin Bay (Fairbridge 1967), and B. sayi (Pfeiffer, 1847) was recorded from a cave deposit near Margaret River and used for dating (Prideaux et al. 2010).

In central Australia, McMichael (1968) and Ludbrook (1980) listed specimens of B. praecursor from north-east inland South Australia (SA). Lowry (1970) discusses an isolated fossil specimen inland c. $145 \mathrm{~km}$ north of Rawlinna, on the southern edge of the Great Victoria Desert.

In this study we aimed to curate the large Western Australian Museum (WAM) Bothriembryon collection to current taxonomy (Breure and Ablett 2012; Breure and Whisson 2012; Stanisic et al. 2018) and to define the geological age of identified Bothriembryon species (where available). 
We also assess the distribution of fossil and modern Bothriembryon in Australia, providing some insights into its origin and radiation.

\section{MATERIALS AND METHODS}

Fossil and modern Bothriembryon data were requested from Australian museums (AM, MV, SAM, WAM, QM, TMAG, MAGNT; see below for abbreviations) and institutes (GA, GSSA). Where locality coordinates were missing (c. $40 \%$ of records) they were approximated using a combination of Google Earth Pro Software (Ver. 7.3.2.5491) and the Geoscience Australia Gazetteer of Australia Place Names (Geoscience Australia 2019). In many cases erroneous localities or coordinates were corrected. Distributional maps were plotted using ArcGIS 10.1 software.

Only those specimens in the WAM Palaeontology Department were examined for identification (or confirmation) using shell morphological characters under a Leica M80 dissecting microscope, and compared with available literature and type specimens. Shell measurements i.e. maximum shell height $(\mathrm{H})$ and maximum shell diameter (D) were taken from intact adult shells using digital callipers to $0.01 \mathrm{~mm}$ and followed the methods figured by Breure (1974: fig. 2).

Stratigraphic dating was made using the International Chronostratigraphic Chart (Cohen et al. 2013) or the Australian Stratigraphic Units Database (ASUD) (Geoscience Australia and Australian Stratigraphy Commission 2018).

To assist with identification, a silicone cast of Bothriembryon from a mould found in pisolitic 'kankar' c. $145 \mathrm{~km}$ north of Rawlinna (WAM 70.158) was produced. The rock sample was first stabilised and sealed using a solution of Butvar B-76 and Ethanol Absolute 100\% BP. The mould was then surrounded by NSP Sulphur-free plasticine and the cast was made using a silicone mix of RTV 3428A/B at a ratio of 10:1, with black Biodur AC 55 used for colour. The apex of the cast was scanned using a Desktop Hitachi TM3030 Plus SEM, fixed in position by carbon tape. Shell images were taken using a Canon 6D digital camera, with the silicone cast coated with ammonium chloride prior to imaging.

Abbreviations used for depositories of material are: AM, Australian Museum, Sydney; FMNH, Field Museum of Chicago, Chicago; GA, Geoscience Australia, Canberra; GSSA, Geological Survey of South Australia, Adelaide; MAGNT, Museum and Art Gallery of Northern Territory, Darwin; MV, Museum of Victoria, Melbourne; NHMUK, Natural History Museum, London; QM, Queensland Museum, South Brisbane; SAM, South Australian Museum, Adelaide; TMAG Tasmanian Museum and Art Gallery, Hobart; WAM, Western Australian Museum, Perth.

\section{RESULTS}

\section{FOSSIL TAXONOMY}

Fossil Bothriembryon were represented by 631 registered lots in Australian museums and institutes: WAM (613 lots), AM (9 lots), GA (4 lots), GSSA (4 lots) and QM (1 lot). No records were located at SAM, TMAG, MAGNT or MV. Additional material was included from the NHMUK (1 lot).

Seven described fossil species and 22 described extant species were identified from fossil material during this study (Table 1). Of the 22 extant species, 15 have a fossil record published for the first time here: $B$. bulla (Menke, 1843); B. dux (Pfeiffer, 1861); B. esperantia Iredale, 1939; B. fuscus Thiele, 1930; B. gratwicki (Cox, 1899); B. indutus (Menke, 1843); B. irvineanus Iredale, 1939; B. jacksoni Iredale, 1939; B. kendricki Hill, Johnson and Merrifield, 1983; B. leeuwinensis (Smith, 1894); B. mastersi (Cox, 1867); B. naturalistarum Kobelt, 1901; B. notatus Iredale, 1939 (treated here as a distinct species from B. kingii); B. perobesus Iredale, 1939; B. sayi.

Sixteen extant species did not have a fossil record: $B$. angasianus (Pfeiffer, 1864); B. balteolus Iredale, 1939; B. bradshawi Iredale, 1939; B. brazieri (Angas, 1871); $B$. decresensis, Cotton 1940; B. distinctus Iredale, 1939; $B$. glauerti Iredale, 1939; B. kingii (Gray, 1825); B. perditus Iredale, 1939; B. praecelsus Iredale, 1939; B. revectus Iredale, 1939; B. richeanus Iredale, 1939; B. sedgwicki Iredale, 1939; B. serpentinus Iredale, 1939; B. sophiarum Whisson and Breure, 2016; B. spenceri (Tate, 1894).

The most abundant species in the fossil collection was B. leeuwinensis ( $>170$ lots). Additionally, several putative new species were recognised during curation of the WAM collection and await description.

\section{GEOGRAPHICAL DISTRIBUTION}

\section{Fossils}

Based on available registered specimens, the geographical distribution of fossil Bothriembryon species is largely restricted to coastal areas within SWWA (at the northern, southern and eastern extremities), central South Australia and south-east Tasmania. However, sparse records from inland, lower Northern Territory and inland northern South Australia exist (Figure 1).

In WA, fossil Bothriembryon specimens have been recorded from along a near continuous distribution from the northern tip of North West Cape south to Rockingham, before a large gap (c. $165 \mathrm{~km}$ ) south to the Busselton area. They are then recorded from Cape Naturaliste to Cape Leeuwin, and after a small gap (c. $55 \mathrm{~km}$ ) intermittently eastward from the Donnelly River mouth to the WA/SA border (including other significant gaps within this range). Records also occur on islands at Shark Bay (Dirk Hartog, Bernier and Dorre Islands), Rottnest Island and some islands of the Recherche Archipelago (Goose, Observatory and Salisbury Islands). Significantly, inland records occur near Tallering Peak, Salmon Gums, Balladonia, Forrest Airport near Reid and north of Rawlinna in the lower Great Victorian Desert. 


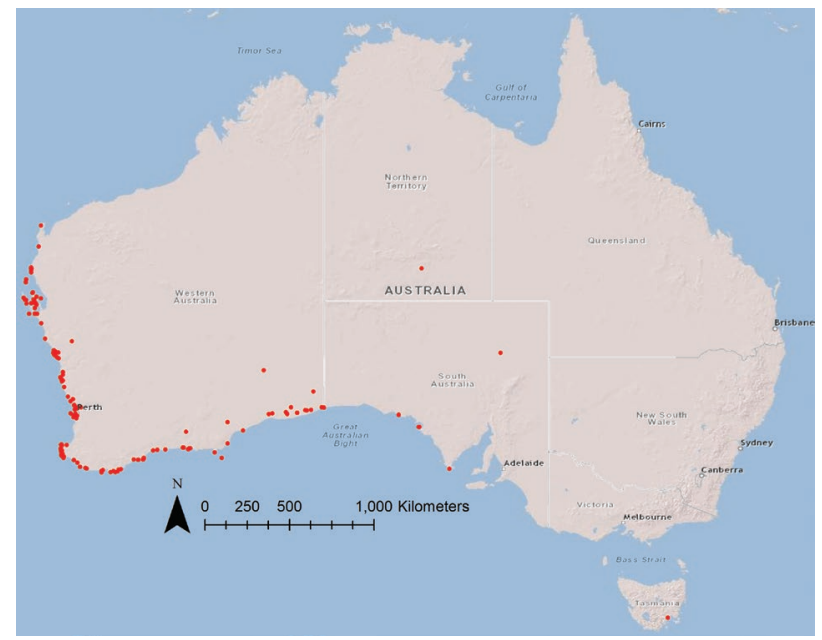

FIGURE 1 Fossil records of Bothriembryon species in Australian museums and institutes (c. 631 lots as of 3 April 2019).

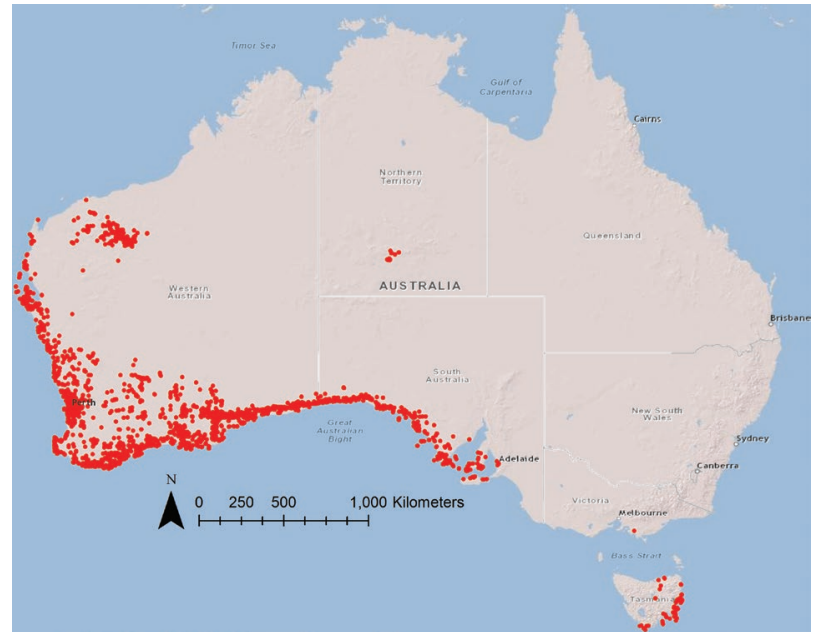

FIGURE 2

Modern records of Bothriembryon species in Australian museums and institutes (c. 7,436 lots as of 3 April 2019).

In South Australia, fossil specimens have been found coastal near Point Sinclair and Cape Bauer, and well inland to the north-east at Lake Palankarinna. In the Northern Territory they have been found in the vicinity of Deep Well Homestead, and in Tasmania, at Hobart. There are noticeable absences from Victoria, New South Wales, Australian Capital Territory and Queensland.

\section{Modern}

Modern records of Bothriembryon were mapped for the first time. This included a total of 7,436 lots from the following Australian museums: WAM (5,709 lots); AM (463 lots); MV (326 lots); SAM (513 lots); FMNH (279 lots); TMAG (76 lots); QM (48 lots) and MAGNT (22 lots).

The geographical distribution of modern Bothriembryon largely mirrors the fossil distribution, having a range from Exmouth in Western Australia, southward to eastern South Australia, with isolated occurrences in lower Northern Territory and eastern Tasmania (Figure 2). A potentially significant specimen has been found from lower Victoria, but label data needs confirmation.

The modern distribution is more prevalent inland than that of the fossils, with populations in the Pilbara and mid-west regions, and scattered occurrences throughout SWWA. The modern occurences in Tasmania also mirror these trends, with more records and more inland incursions.

\section{GEOLOGICAL AGE}

The geological age of Bothriembryon spans from a minimum Late Oligocene ( $\geq 25.7$ MYA), based on the stratigraphy of the extinct Tasmanian B. gunnii (Kershaw 1981), to recent (= Holocene). Specimens of the extinct B. praecursor from the Etadunna Formation in South Australia (WAM 70.1801) are more defined, being Late Oligocene to Miocene (25.7-12.5 MYA) (Table 1).

All extant, endemic Western Australian species have a Pleistocene age (2.58 MYA-11.7 KYA). Similarly all extinct, endemic Western Australian species terminate in the Pleistocene. Some extant species, which occur across the Nullarbor into South Australia (B. barretti, $B$. indictus Iredale, 1939) were recorded as older, being dated as Late Pliocene to Early Pleistocene (2.6-1.8 MYA) from the Roe Calcarenite formation. The extinct Nullarbor species B. kremnobates can be traced back to the late Pliocene. A specimen from c. $145 \mathrm{~km}$ north of Rawlinna (WAM 70.158, Figure 3 and 4) identified as $B$. cf. praecursor during this study, was tentatively dated as Pliocene to Pleistocene (5.33 MYA-11.7 KYA) (Lowry 1970).

\section{SHELL SIZE}

The adult internal cast from Rawlinna (WAM 70.159) measured $21.83 \mathrm{~mm} \mathrm{H}, 12.80 \mathrm{~mm} \mathrm{~W}$ and $1.705 \mathrm{H} / \mathrm{W}$ (Figure 3F-H). The inland specimen from near Reid, identified as B. cf. praecursor (WAM 78.297) measured $27.95 \mathrm{~mm} \mathrm{H}, 14.84 \mathrm{~mm} \mathrm{~W}$ and $1.883 \mathrm{H} / \mathrm{W}$ (Figure 3D-E).

\section{SHELL PRAEDICHNIA}

Fossil shells of several extant species showed signs of extensive predation, typically having the shell spires removed. This was most common for the species $B$. leeuwinensis in cave deposits along the Cape LeeuwinCape Naturaliste Ridge (Figure 5). Similarly, but less frequently, it was noted for the species $B$. perobesus in cave deposits near the mid-west coast as well as the rock dwelling $B$. indutus. It was also noticed in extinct species such as B. consors and B. douglasi.

\section{DATA SET}

An excel file of the curated WAM Bothriembryon fossil collection is available upon request to the WAM Palaeontology Section. 


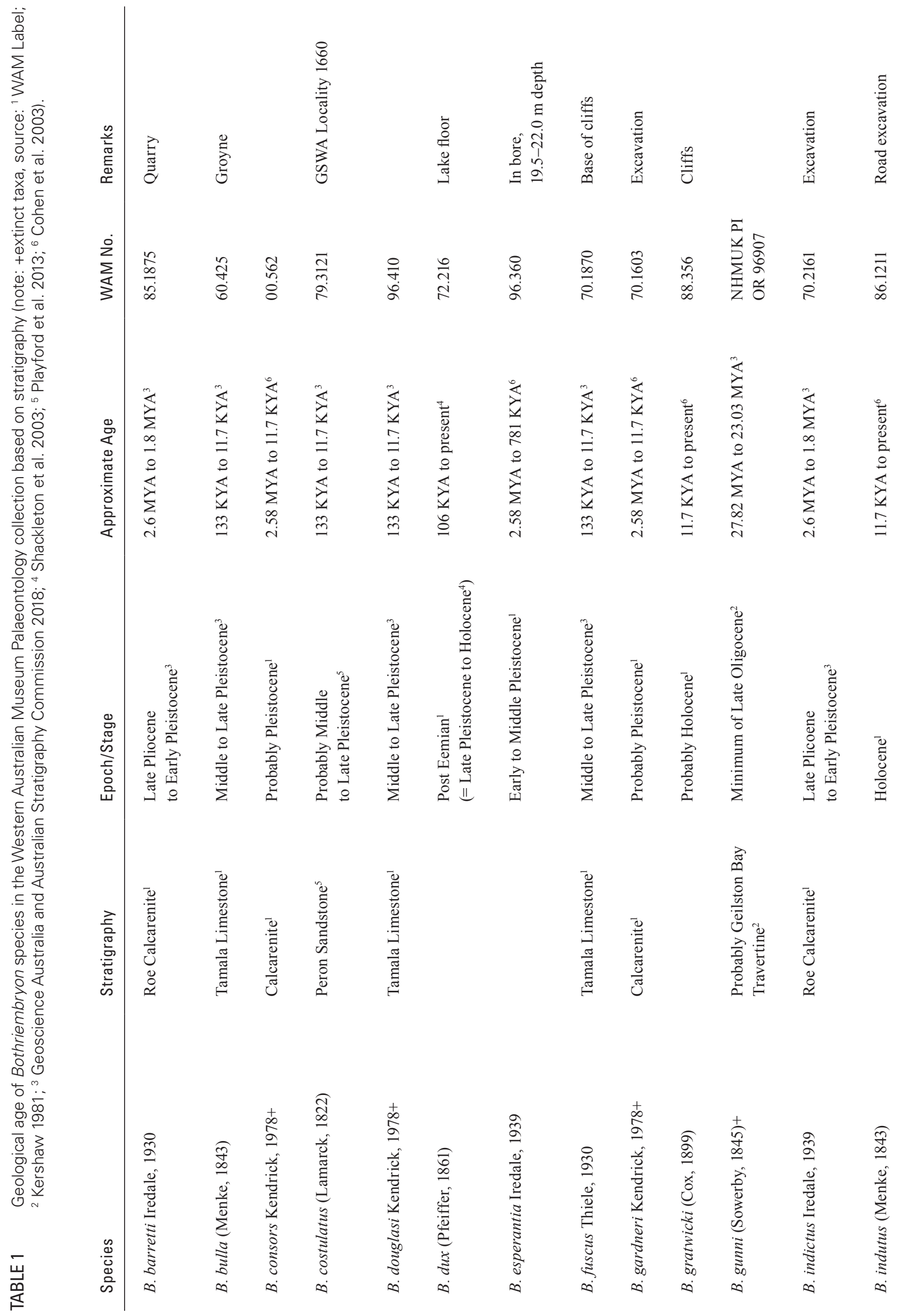




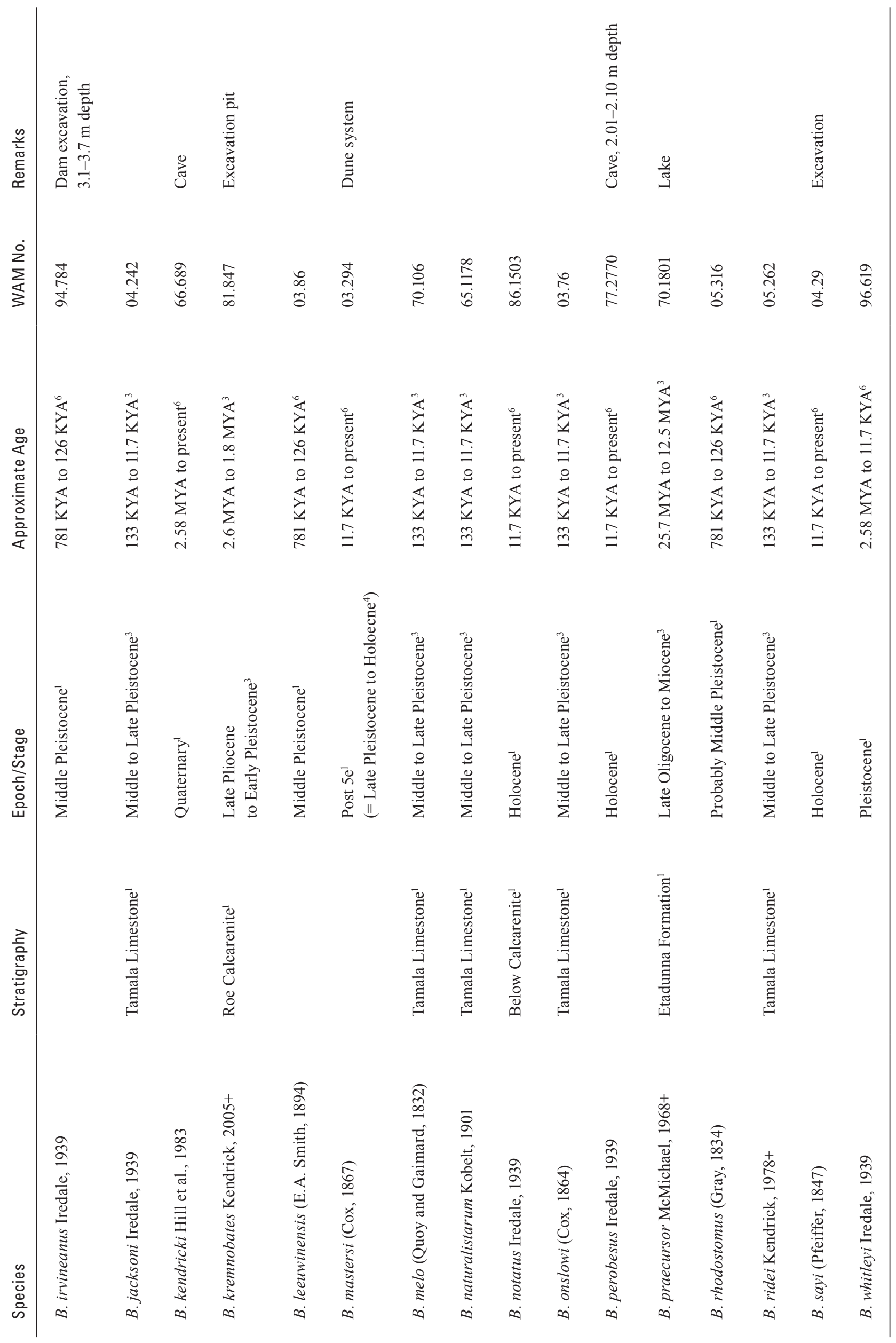




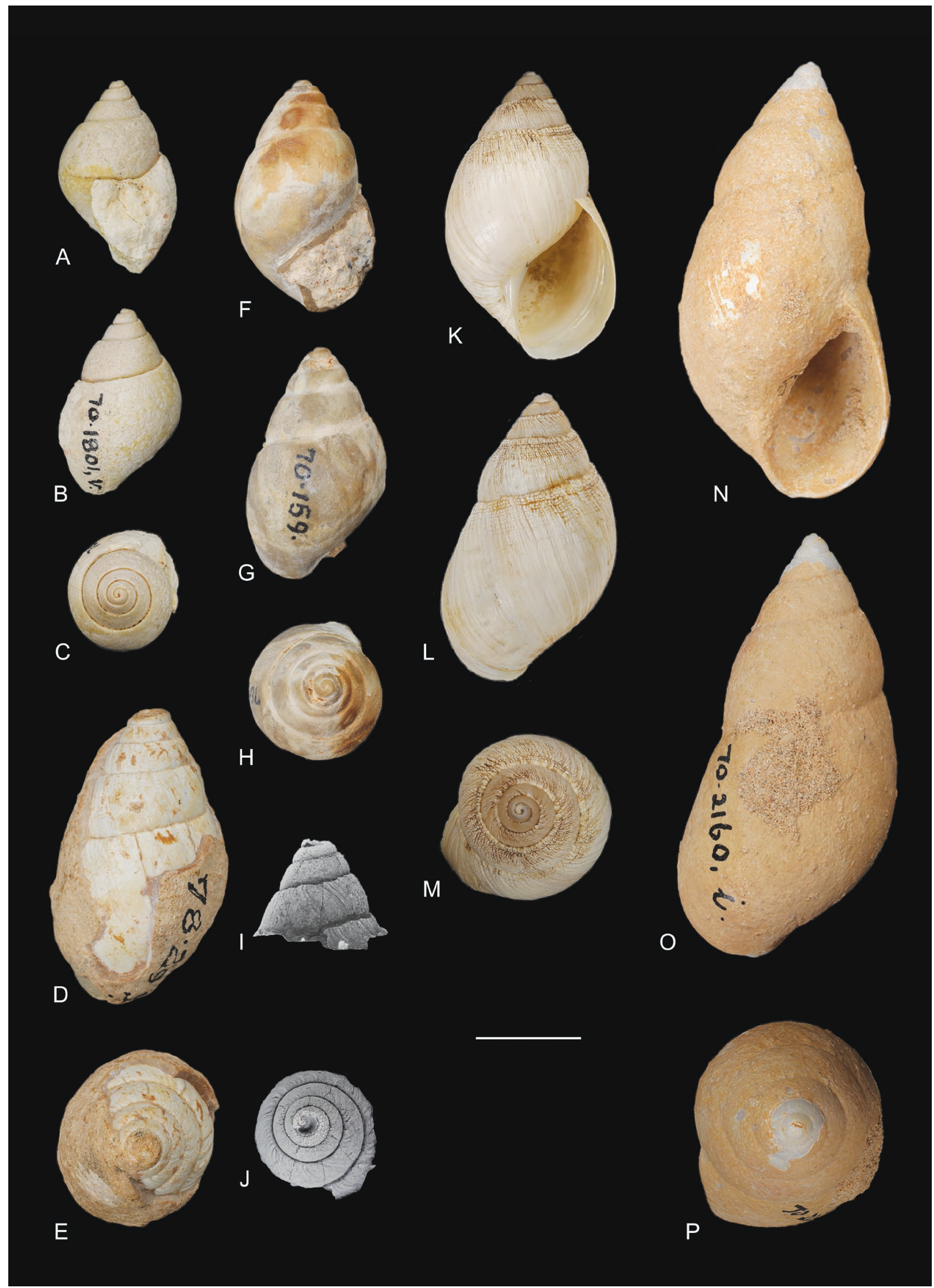

FIGURE 3 Plate of fossil and modern Bothriembryon species from the Nullarbor region and north-east South Australia. A-C, B. praecursor. WAM 70.1801v; D-J, B. cf. praecursor, D-E: WAM 78.297; F-H: WAM 70.159; I-J: WAM 70.158g (cast); K-M, B. barretti, WAM S1635; N-P, B. indictus: WAM 70.2160i. Scale bar $=10 \mathrm{~mm}$. 


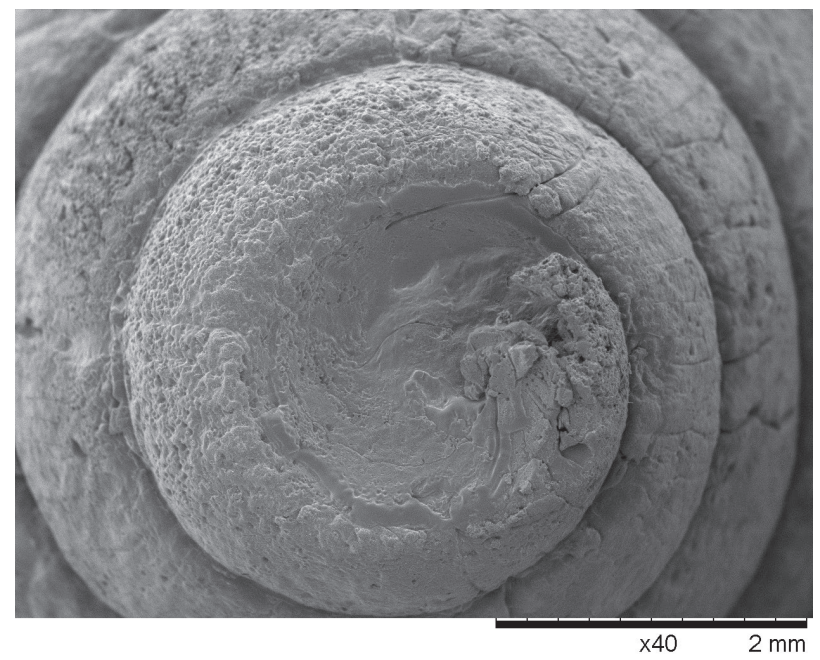

FIGURE 4 SEM image of protoconch and early teleoconch whorls of silicon cast of Bothriembryon cf. praecursor fossil from c. $145 \mathrm{~km}$ north of Rawlinna, WA (WAM 70.158g), 40x magnification.

\section{DISCUSSION}

Smith and Stanisic (1998) remarked that no detailed taxonomic analysis had been made on fossil Australian molluscs and this deficit still exists. Furthermore, fossil identification to family and genus level has been based purely on shell characters, a problem exacerbated by the incomplete knowledge of extant taxa. This study treated the relatively large WAM fossil Bothriembryon collection ( $\mathrm{n}=613$ lots) using modern taxonomic literature (Breure and Ablett 2012; Breure and Whisson 2012; Stanisic et al. 2018), resulting in many specimens being identified or having their identifications corrected. These new data enabled previous evolutionary hypotheses on Bothriembryon to be investigated, and demonstrated the value of taxonomic curation of a fossil collection, which are often poorly identified (Smith and Stanisic 1998). For example, numerous fossil records at WAM, previously identified as $B$. sayi, and presumably published as such (e.g. Prideaux et al. 2010) were in fact B. leeuwinensis. This matter needs further investigation as syntypes of B. leeuwinensis at WAM (WAM S15124) contained a mix of B. leeuwinensis and B. sayi specimens (Figure 5). The fossil collection also contained specimens of rare or presumed extinct species, such as B. gratwicki (WAM 68.10) and B. whitleyi (WAM 68.10).

Assembling fossil Bothriembryon data from Australian museums and institutes, combined with curation of the WAM Palaeontology collection, did not significantly expand the overall geographical distribution or geological age of the group, compared with available literature. However, the study provided accurate identifications and localities, and for available species, defined their oldest geological age. This large combined data set (and data gaps or absences) may provide new insights into the origin, radiation and past occupation of Bothriembryon in Australia. The fossil record for fauna from the SWWA is regarded as limited, but inclusion of fossil material enables phylogenetic dating and may generate new insight into evolution of SWWA biota (Rix et al. 2014).

Fossil pulmonates in Australia are regarded as being late Tertiary or Quaternary in age (Smith and Stanisic 1998), although Bishop (1981) reports no records prior to the Miocene. The oldest geological age of Bothriembryon being Late Oligocene i.e. B. gunnii and $B$. praecursor, falls within the Tertiary. The probable young geological age of Western Australian species compared with the slightly older age of Nullarbor species, and much older age of specimens from inland NT and SA and south-east Tasmania, may provide evidence for ancestry and radiation of the group. However, older records may exist (or existed) in more inland parts of WA but did not fossilise well or have not yet been exposed. This is because large parts of inland WA, known as cratons, are tectonically stable, long-term emergent crustal blocks with a thin and poorly preserved sedimentary cover. As such these areas are often overlooked in palaeoenvironmental studies (de Broekert and Sandiford 2005).

It is suggested the occurrence of specimens in Tertiary deposits from central Australia (i.e. B. praecursor) may support the hypothesis that the genus was once more widespread across Australia (McMichael and Iredale 1959; McMichael 1968; Kendrick 1983). It is proposed as the landscape aridified from the mid Miocene, c. 15 MYA (Byrne et al. 2008), Bothriembryon contracted to mesic SWWA, leaving a somewhat patchy occurrence in northern areas (McMichael 1968; Kendrick 1983). Whilst this contraction may be the case for some Bothriembryon taxa (e.g. B. kingii group, B. fuscus), it could have been an opportunity for expansion of others.

McMichael (1968) and Ludbrook (1980) suggested $B$. praecursor was similar morphologically (and probably ecologically) to the Nullarbor B. barretti and may be ancestral, although Solem (1988) remarked the fossil specimens were not in appropriate condition for comparison to other species. In the opinion of the senior author the specimens of $B$. praecursor listed by McMichael (1968) and Ludbrook (1980) more closely resemble the Nullarbor group of species $B$. perditus, B. barretti, B. indictus and perhaps B. kremnobates than other Bothriembryon groups (Figure 3), based primarily on shell shape. However, Kendrick (2005) did not include the latter species. Given the slightly older geological age of these Nullarbor species i.e. Pliocene, as opposed to younger Pleistocene SWWA species (Table $1)$, a radiation of the $B$. praecursor lineage southward may have occurred during the late Miocene glaciation, when the Nullarbor was not inundated by marine waters (Isem et al. 2001), combined with favourable aridification through to the Pleistocene (Hill 1994). The inland Bothriembryon record located c. $145 \mathrm{~km}$ north of Rawlinna and tentatively aged as Pliocene (Lowry 1970) may further support this hypothesis. Lowry (1970) 


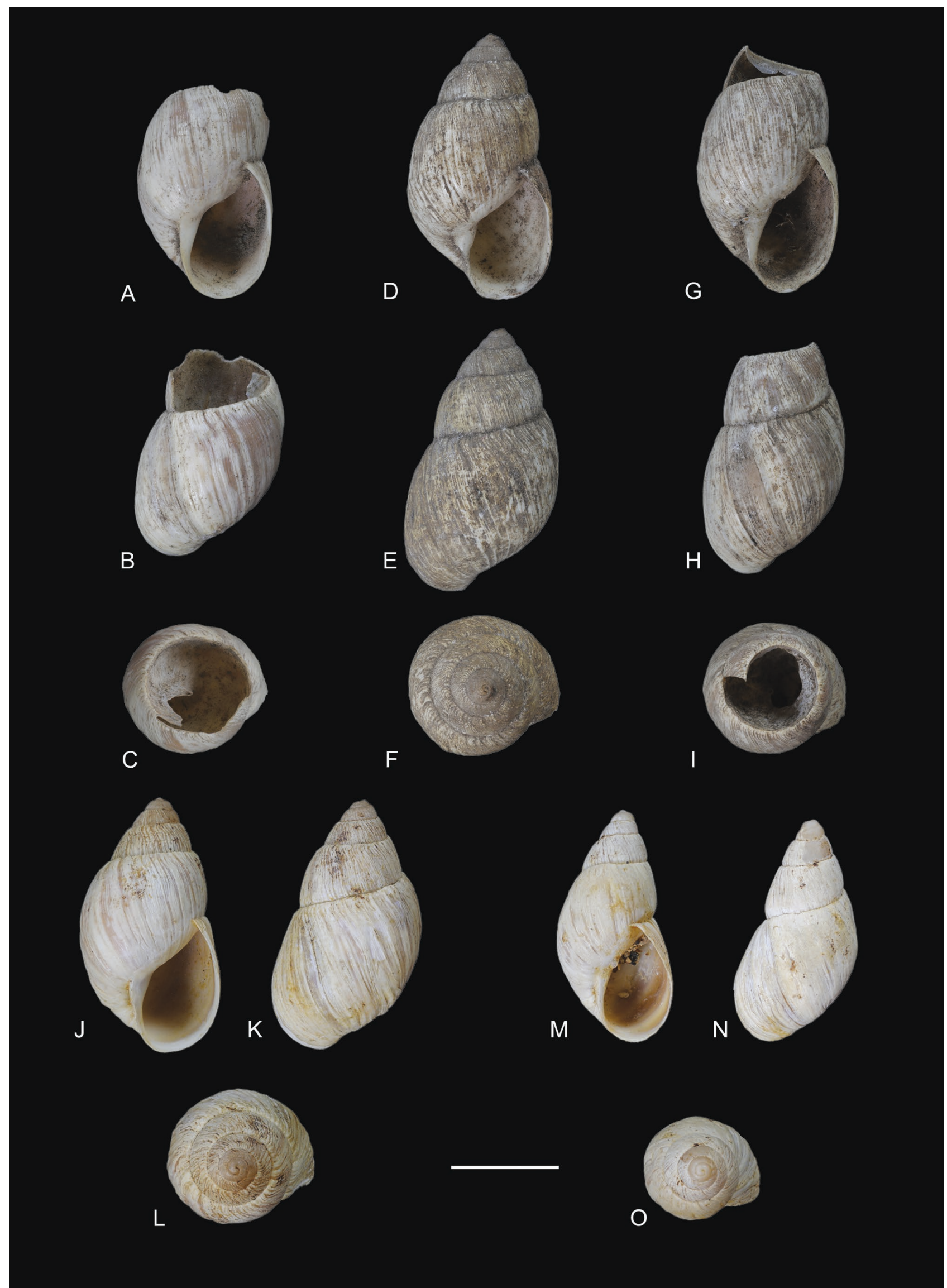

FIGURE 5

Plate of fossil and modern Bothriembryon from along the Cape Naturaliste-Cape Leeuwin Ridge. A-I, B. leeuwinensis cave subfossils: A-C, predated shell, WAM 04.25a; D-F, intact adult shell, WAM 04.25b; G-I, predated shell, WAM 04.25c; J-O, B. leeuwinensis mixed syntype lot: WAM S15124, J-L, B. leeuwinensis adult shell, M-O, B. sayi adult shell. Scale bar $=10 \mathrm{~mm}$. 
suggested this fossil resembled the Nullarbor species $B$. barretti, but based on morphology and size of the adult internal cast (WAM 70.159, Figure 3F-H), and part silicone external cast (Figure 3I-J and 4) generated in this study, suggests it could be $B$. praecursor. The adult internal cast from Rawlinna (WAM 70.159) measured $21.83 \mathrm{~mm} \mathrm{H}, 12.80 \mathrm{~mm} \mathrm{~W}, 1.705 \mathrm{H} / \mathrm{W}$, and although larger than the holotype $(14.17 \mathrm{~mm} \mathrm{H}, 9.00 \mathrm{~mm} \mathrm{~W}, 1.574$ H/W) (Breure and Whisson 2012), it lies close to the average size range of specimens $(22.4 \mathrm{~mm} \mathrm{H}, 13.5 \mathrm{~mm}$ W, $1.66 \mathrm{H} / \mathrm{W}$ ) listed by Ludbrook (1980).

Additionally, an inland (c. $100 \mathrm{~km}$ from coast) undated, strongly lithified fossil from a cave near Forrest Airport, Reid WA was identified as B. cf. praecursor (WAM 78.297, Figure 3D-E), again being larger $(27.95 \mathrm{~mm} \mathrm{H}, 14.84 \mathrm{~mm} \mathrm{~W}, 1.883 \mathrm{H} / \mathrm{W})$ than the holotype. The likely late Pleistocene fossil specimen from St Francis Island in South Australia, tentatively identified as B. barretti (Kershaw 1985, 1986), suggests expansion of this Nullarbor group eastward during the arid Pleistocene, and may indicate a close relationship to Bothriembryon species in South Australia. Another similar species in this Nullarbor group, B. dux, was recorded in Pleistocene deposits at Salmon Gums, toward the west end of its range.

The other major land snail family in Australia is the Camaenidae, long suspected as having an Asian origin (Solem 1997; Hugall and Stanisic 2011). Solem (1993) suggested a 'red centre' source for the Camenidae subfamily Sinumeloninae, which then colonised the Nullarbor and mid-west coast of Western Australia. Like Bothriembryon, the subfamily is absent from northern Australia and along the east coast (Solem 1993, 1997). Typically Camaenidae and Bothriembryon are allopatric, but along the Nullarbor and mid-west coast of WA they are broadly sympatric, suggesting a similar biogeographic history (Scott 1997).

The absence of fossil data is perhaps equally as meaningful as the presence of data, with much of eastern Australia i.e. Queensland, New South Wales, Canberra and Victoria void of Bothriembryon (Kershaw 1985). The isolated red centre B. spenceri, with no continuous connection to the modern or fossil biogeography of Bothriembryon, may suggest a different origin for this species, particularly as its shell morphology (shape) is not typical of the SWWA forms and more closely resembles that of South American or African bothriembryontids such as Prestonella Connolly, 1929 and Plectostylus H. Beck, 1837. Perhaps it is a relictual Gondwanan taxon surving in climatic refugia as suggested by previous authors (Bishop 1981; Kendrick 1983; Solem 1993; Ponder et al. 1998). Similarly B. tasmanicus appears to lack a fossil or modern connection with mainland Australian species and also has a shell morphology (shape) with closer affinity to South American or African bothriembryontids Prestonella and Plectostylus. Other workers have argued the placement of $B$. tasmanicus within the genus
Bothriembryon is provisional (McMichael and Iredale 1959; Bishop 1981) including the geographically nearby extinct B. gunnii (Solem 1988; Smith and Stanisic 1998). However McMichael (1968) suggested that B. gunnii was similar to B. leeuwinensis from SWWA. Smith (1984) remarked that the origin of B. tasmanicus and a southern South Australian species (name not listed) was unknown, with no fossil record to assist these questions.

Many of the endemic SWWA species were not preserved in the fossil record and many areas in SWWA lack Bothriembryon fossils. Whilst this might reflect poor fossil record preservation caused by geological activity, it could also offer insight into the origin and radiation of Bothriembryon. In WA a large number of fossils have been found in the Shark Bay area, along the Cape Leeuwin to Cape Naturaliste Ridge (Figure 5), particularly in cave deposits (e.g. Skull Cave) and along the Nullarbor. Kendrick (1983) suggested species on the Cape Leeuwin to Cape Naturaliste Ridge originated from a south coast ancestor(s), due to the lack of modern or fossil records to the east and north. The large fossil record gap between Rockingham and Busselton, and east of the Cape Leeuwin to Cape Naturaliste Ridge supports this hypothesis.

New records generated from this study may indicate a previous broader geographical occupation of Bothriembryon. The large fossil shells from Salisbury Island, located on the mid continental shelf c. $50 \mathrm{~km}$ from mainland (eastern Recherche Archipelago), tentatively identified as $B$. rhodostomus represent one of the outer-most island records of the group, and likely provide evidence of occupation during past glaciation events. A record of tentatively B. rhodostomus from the mainland near Esperance (WAM 67.380) may be ancestral to the island radiation of this group, but requires more work. These specimens resemble the form B. rhodostomus hullianus from the type locality Gunton Island. In the northern part of WA, fossil species $B$. ridei and $B$. douglasi were recorded from Bernier Island in Shark Bay (Kendrick 1978), a similar distance offshore as Salisbury Island. The Tallering Peak record, likely an un-named species, represents a significant inland occupation (c. $120 \mathrm{~km}$ from Geraldton) at northern latitudes. Slack-Smith (1993) suggested an unidentified Bothriembryon fossil of Pleistocene age from the Cape Range area may indicate that the northern range of Bothriembryon has contracted.

In SWWA, fossil records of B. fuscus have been recorded from coastal areas such as Point D'Entrecasteaux (WAM 04.40, undated) and Broke Inlet (WAM 70.1870, Pleistocene), which is west of the type localities of Walpole and Denmark (Breure and Whisson 2012). As B. fuscus is a karri forest species (Iredale 1939; Stanisic et al. 2018), these records might indicate larger coastal stands of karri during more mesic times. A slightly broken specimen of B. gardneri was identified during this study from just south of Albany (WAM 69.428) extending its known range some 175 
$\mathrm{km}$ eastward. Kendrick (1978) remarked the slightly larger B. gardneri may have been ancestral to B. fuscus, and as such this record from Albany may indicate past occupation of this karri associated species group further eastward. On the Cape Leeuwin-Cape Naturaliste Ridge, B. irvineanus was recorded from as far south as the Boranup area and south-east to Nannup, which sits outside of its type locality of Cape Naturaliste.

Kendrick and Wilson (1975) suggested that as a result of increasing aridity during the Pleistocene, the Shark Bay species B. onslowi and B. costulatus reduced in shell size, whilst the larger $B$. douglasi and $B$. ridei became extinct, unable to cope with decreasing humid conditions (Kendrick 1978). During this study, a considerable number of the specimens previously identified as larger-sized Pleistocene B. costulatus (e.g. WAM 74.532, 66.1037, 66.288, 05.298) and B. onslowi (e.g. WAM 05.262, 79.3120, 87.247), presumably discussed by Kendrick and Wilson (1975) and listed by Kendrick (1978) were re-identified. They were mostly re-identified as the larger fossil species $B$. douglasi and $B$. ride $i$, or in the case of $B$. costulatus, sometimes the larger B. onslowi. Presumably Kendrick (1978) did not revisit the $B$. costulatus and $B$. onslowi material when describing the new fossil species $B$. douglasi and $B$. ridei and discussing size differences. Therefore the hypothesis of decreased shell size in a Bothriembryon species over time, due to increasing aridity as suggested by Kendrick and Wilson (1975) requires further work.

An additional hypothesis is that ancestors of some Bothriembryon taxa were larger in shell size. For example, large Pleistocene specimens of B. consors were identified during this study from near the coast southwest of Albany (WAM 07.495), extending its known range some $165 \mathrm{~km}$ eastward. The shells possess axial stripes and are similar in size to the larger $B$. jacksoni in the B. kingii group. Perhaps $B$. consors was ancestral to the B. kingii group as suggested by Kendrick (1978), who also proposed a young (i.e. Quaternary) radiation for the B. kingii group. Bothriembryon consors may have been more widespread during mesic times, but with increasing aridity during the Pleistocene became disjunct due to a fragmenting habitat. Aridity, likely to be more extreme to the eastern parts of its range, could have resulted in the extinction of larger lineages, with smaller, more xeric tolerant lineages able to survive. Rix et al. (2014) suggests that Bothriembryon may have contained susceptible mesic-adapted lineages that became isolated due to increasing aridificiation, driving allopatric speciation. There are numerous examples of relatively large species confined to the Pleistocene aridification such as $B$. gardneri, B. ridei, B. douglasi and B. consors (Kendrick 1978).

This study demonstrated that cave desposits provide an excellent source of fossil Bothriembryon material for a range of species (e.g. B. leeuwinensis, B. perobesus and $B$. dux). This is not unexpected as caves provide a favourable environment (i.e. stable temperature and humidity) for the preservation of animal fossils (van der Geer and Dermitzakis 2013). The observations of predation seen in many fossil Bothriembryon shells (largely those in caves) may have been be caused by rodents, given the nature of the broken shells (i.e. apex removal) as suggested by Solem (1998). Rodents often build dens and middens in caves, which are usually accumulations of the surrounding biota (Breed and Ford 2007).

\section{ACKNOWLEDGEMENTS}

Significant acknowledgement is given to work of the late George Kendrick who curated large parts of the WAM Palaeontology Bothriembryon collection. Bram Breure provided advice and valuable comments on the manuscript. CW thanks his supervisors Lisa Kirkendale and Alan Lymbery for reviewing the manuscript, and for encouraging him to examine the palaeontological aspect of Bothriembryon. HR thanks Kirsten Tullis for assisting with the silicone cast production. We thank the following museum staff for providing information on fossil holdings: Mikael Siversson (WAM); Mandy Reid (AM); Darryl Potter (QM); Rolf Schmidt (MV); Andrea Crowther (SAM); Catherine Byrne (TMAG); Richard Willan and Gavin Dally (MAGNT); Natalie Schroeder (GA) and Lyn Broadbridge (GSSA). The manuscript was much improved by the insights of two reviewers. This publication was funded in part by a Research Training Scheme (RTS) grant to CW that forms part of a Masters of Philosophy (MPhil) degree at Murdoch University.

\section{REFERENCES}

Angas, G.F. (1871). Descriptions of thirty-four new species of shells from Australia. Proceedings of the Zoological Society of London 1871: 13-21.

Beck, H. (1837). Index molluscorum praesentis aevi musei principis augustissimi Christiani Frederici. Hafniae: Copenhagen.

Behrensmeyer, A.K., Damuth, J.D., DiMichele, W.A., Potts, R., Sues, H.-D. and Wing, S.L. (1992). Terrestrial ecosystems through time: Evolutionary paleoecology of terrestrial plants and animals. University of Chicago Press: Chicago.

Bishop, M.J. (1981). The biogeography and evolution of Australian land snails. In: Keast, A. (ed.) Ecological biogeography of Australia. Dr. W. Junk Publishers: London.

Breed, B. and Ford, F. (2007). Native mice and rats. CSIRO Publishing: Collingwood.

Breure, A. (1974). Caribbean land molluscs: Bulimulidae, I. Bulimulus. Studies on the Fauna of Curaçao and Caribbean Islands 45: 1-80.

Breure, A. and Ablett, J.D. (2012). Annotated type catalogue of the Bothriembryontidae and Odontostomidae (Mollusca, Gastropoda, Orthalicoidea) in the Natural History Museum, London. ZooKeys 182: 1-70.

Breure, A. and Whisson, C.S. (2012). Annotated type catalogue of Bothriembryon (Mollusca, Gastropoda, Orthalicoidea) in Australian museums, with a compilation of types in other museums. ZooKeys 194: 41-80. 
de Broekert, P. and Sandiford, M. (2005). Buried InsetValleys in the Eastern Yilgarn Craton, Western Australia: Geomorphology, Age, and Allogenic Control. The Journal of Geology 113: 471-493.

Byrne, M., Yeates, D.K., Joseph, L., Kearney, M., Bowler, J., Williams, M.A.J., Cooper, S., Donnellan, S.C., Keogh, J.S., Leys, R., Melville, J., Murphy, D.J., Porch, N. and Wyrwoll, K.H. (2008). Birth of a biome: insights into the assembly and maintenance of the Australian arid zone biota. Molecular Ecology 17: 4398-4417.

Cohen, K.M., Finney, S.C., Gibbard, P.L. and Fan, J.X. (2013 updated). The ICS International Chronostratigraphic Chart. Episodes 36: 199-204. Available at: http:// stratigraphy.org/ICSchart/ChronostratChart2018-08.pdf

Connolly, M. (1929). New non-marine Mollusca from South Africa. Annals of the Natal Museum 6: 219-244.

Cotton, B.C. (1940). The land shells of Kangaroo Island. The South Australian Naturalist 19: 40-43.

Cox, J.C. (1864). Descriptions of twenty-six new species of Australian land-shells. Annals and Magazine of Natural History 3: 180-185.

Cox, J.C. (1867). Characters of four new species of Australian land-shells. Proceedings of the Zoological Society of London 1867: 39-40.

Cox, J.C. (1899). Description of a new species of Liparus from West Australia. Proceedings of the Linnean Society of New South Wales 24: 435-436.

Cram, V. (2010). No Title. The Malacological Society of Australasia Newsletter. Victoria Branch Bulletin 253: 1-6.

Fairbridge, R.W. (1967). Carbonate rocks and paleoclimatology in the biochemical history of the planet. In: Chilingar, G., Bissell, H., and Fairbridge, R.W. (eds.) Developments in Sedimentology 9A: Carbonate Rocks: Origin, Occurrence and Classification. Elsevier Publishing Company: Amsterdam.

Forey, P.L., Fortey, R.A.,Kenrick, P., and Smith, A.B (2004). Taxonomy and fossils: a critical appraisal. Philosophical Transactions of the Royal Society of London. Series B: Biological Sciences 359: 639-653.

Geoscience Australia. (2019). Gazetteer of Australia Place Name Search [Online]. Available at: http://www.ga.gov.au/ placename [Accessed: 1 March 2019].

Geoscience Australia and Australian Stratigraphy Commission. (2018). Australian Stratigraphic Units Database. Available at: https://asud.ga.gov.au/ [Accessed: 30 March 2019].

Gray, J.E. (1825). A list and description of some species of shells not taken notice of by Lamarck. Annals of Philosophy 9: 134-140.

Harper, D. and Brenchley, P. (1998). Palaeoecology: Ecosystems, Environments and Evolution. CRC Press: London.

Hearty, P.J. (2003). Stratigraphy and timing of eolianite deposition on Rottnest Island, Western Australia. Quaternary Research 60: 211-222.

Hill, R.S. (1994). History of the Australian Vegetation: Cretaceous to Recent. Cambridge University Press: Cambridge.

Hill, A., Johnson, M.S. and Merrifield, H. (1983). An electrophoretic and morphological examination of Bothriembryon kendricki (Pulmonata: Bulimulidae), a new species previously considered conspecific with $B$. bulla (Menke). Australian Journal of Zoology 31: 227-242.

Hugall, A.F. and Stanisic, J. (2011). Beyond the prolegomenon: a molecular phylogeny of the Australian camaenid land snail radiation. Zoological Journal of the Linnean Society 161: 531-572.

Iredale, T. (1939). A review of the land Mollusca of Western Australia. Records of the Western Australian Museum and Art Gallery 2: 1-88.

Isem, A.R., Brakel, A.T., Olissoff, S., Strusz, D.L., Langford, R.P., Truswell, E.M., Yeung, M., Cook, P.J., Bradshaw, M.T., Wilford, G.E., Yeates, A.N. and Totterdell, J.M. (2001). Palaeogeographic Atlas of Australia (a set of ten volumes) [Online]. Available at: https://researchdata. ands.org.au/palaeogeographic-atlas-australia-setvolumes/1298647?source=suggested_datasets [Accessed: 1 February 2019].

Jell, P.A. and Darragh, T.A. (1998). The Fossil Record. In: Beesley, P.L., Ross, G.J.B. and Wells, A. (eds.), Mollusca: The Southern Synthesis: Fauna of Australia. CSIRO Publishing: Melbourne.

Kendrick, G. (1978). New species of fossil non-marine molluscs from Western Australia and evidence of late Quaternary climate change in the Shark Bay district. Journal of the Royal Society of Western Australia 60: 49-60.

Kendrick, G.W. (2005). A new species of Bothriembryon (Mollusca: Gastropoda: Bulimulidae) from the Pliocene Roe Calcarenite, Eucla Basin, Western Australia. Records of the Western Australian Museum 22: 309-313. doi: 10.18195/ issn.0312-3162.22(4).2005.309-313.

Kendrick, G.W. and Wilson, B.R. (1975). Nomenclatural notes on the land snail genus Bothriembryon Pilsbry, 1894 (Pulmonata: Bulimulidae), with redescriptions of the types and two other species. Records of the Western Australian Museum 3: 295-325.

Kendrick, P.G. (1983). Biochemical and morphological systematics of Bothriembryon. University of Western Australia. Honours Thesis.

Kershaw, R.C. (1981). The validity of the taxon Bothriembryon tasmanicus (Pulmonata: Bulimulidae). Records of the Queen Victoria Museum 73: 1-8.

Kershaw, R.C. (1985). The distribution of Bothriembryon tasmanicus (Pfeiffer, 1853) (Pulmonata: Bulimulidae). The Tasmanian Naturalist 80: 3-7.

Kershaw, R.C. (1986). Anatomical notes on the land snails Bothriembryon (Pulmonata: Bulimulidae) from South Australia and Western Australia. Records of the South Australian Museum 19: 327-337.

Kobelt, W. (1899-1902). Die Familie Buliminidae. In: Kuster, H.C. and Kobelt, W. (eds.) Systematisches ConchylienCabinet von Martini und Chemnitz.

Lamarck, J.B.P.A de (1822). Histoire naturelle des animaux sans vertèbres. Tome sixième, deuxième partie. Verdières: Paris.

Lowry, D.C. (1970). Geology of the Western Australian part of the Eucla Basin. Geological Survey of Western Australia Bulletin 122: 201.

Ludbrook, N.H. (1963). Investigation of Lake Eyre. Part II. Subsurface stratigraphy. Report of Investigations of the Geological Survey of South Australia 24: 73-88.

Ludbrook, N.H. (1978). Quaternary molluscs of the western part of the Eucla Basin. Geological Survey of Western Australia 125: $1-286$.

Ludbrook, N.H. (1980). Non-marine molluscs from dolomitic limestones in the north of South Australia. Transactions of the Royal Society of South Australia 104: 83-92.

Menke, C.T. (1843). Molluscorum Novae Hollandiae Specimen in Libraria Aulica Hahniana. Libraria Aulica Hahniana: Hannoverae. 
McMichael, D. (1968). Non-marine Mollusca from Tertiary rocks in northern Australia. Bureau of Mineral Resources, Geology and Geophysics Bulletin 8: 133-160.

McMichael, D. and Iredale, T. (1959). The land and freshwater mollusca of Australia. In: Keast, A., Crocker, R.L., and Christian, C.S. (eds.) Biogeography and Ecology in Australia. Junk: Den Haag, Netherlands.

McNamara, K.J., Long, J.A. and Brimmell, K. (1991). Catalogue of type fossils in the Western Australian Museum. Records of the Western Australian Museum Supplement 39: 1-106.

Peppe, D.J. and Deino, A.L. (2013). Dating Rocks and Fossils Using Geologic Methods. Nature Education Knowledge 4: 1.

Pfeiffer, L. (1847). Descriptions of thirty-eight new species of land shells, in the collection of Hugh Cuming, Esq. Proceedings of the Zoological Society of London 1846: 109-116.

Pfeiffer, L. (1853). Descriptions of fifty-four new species of Helicea, from the collection of Hugh Cuming, Esq. Proceedings of the Zoological Society of London 1851: 252-263.

Pfeiffer, L. (1861). Description of fifty-seven new species of land-shells, from the collection of H. Cuming, Esq. Proceedings of the Zoological Society of London 1861: 20-29.

Pfeiffer, L. (1864). Description of ten new species of landshells, from the collection of George French Angas, Esq. Proceedings of the Zoological Society of London 1863: 526-529.

Pilsbry, H. (1894). Note on Liparus. Nautilus 8: 35-36.

Playford, P.E., Cockbain, A.E., Berry, P.F., Roberts, A.P., Haines, P.W. and Brooke, B.P. (2013). The Geology of Shark Bay. Geological Survey of Western Australia Bulletin 146: 1-282.

Ponder, W.F., Wells, F.E. and Solem, A. (1998). Distributions and affinities of non-marine molluscs. In: Beesley, P.L., Ross, G.J.B. and Wells, A. (eds.) Mollusca: The Southern Synthesis: Fauna of Australia. Part A. CSIRO Publishing: Melbourne.

Prideaux, G., Gully, G., Couzens, A., Ayliff, L., Jankowski, N., Jacobs, Z., Roberts, R., Hellstrom, J., Gagan, M. and Hatcher, L. (2010). Timing and dynamics of Late Pleistocene mammal extinctions in southwestern Australia. Proceedings of the National Academy of Sciences 107: 1-6.

Quoy, J.C.R. and Gaimard, J.P. (1832). Mollusques, 1. In: Dumont d'Urville, J.S.C. (ed.), Voyage decouvertes de l'Astrolabe exécuté par ordre du Roi, pendant les années 1826-1827-1828-1829, sous le commandement de M.J. Dumont d'Urville. Zoologie, Tome second. J. Tastu: Paris.

Richardson, C.L. (1995). Bulimulidae: catalog of species. Tyronia 28: 1-458.

Rix, M.G., Edwards, D.L., Byrne, M., Harvey, M.S., Joseph, L. and Roberts, J.D. (2014). Biogeography and speciation of terrestrial fauna in the south-western Australian biodiversity hotspot. Biological Reviews 90: 1-34.

Schneider, B. and Morrison, H. (2018). A new species of the genus Bothriembryon (Gastropoda, Stylommatophora: Bothriembryontidae) from South Eastern Western Australia. Conchylia 49: 1-11.

Shackleton, N., Sanchez-Goni, M.F., Pailler, D. and Lancelot, Y. (2003). Marine Isotope Substage 5e and the Eemian Interglacial. Global and Planetary Change 36: 151-155.

Scott, B. (1997). Diversity in central Australian land snails (Gastropoda: Pulmonata). Memoirs of Museum Victoria 56: 435-439.
Slack-Smith, S. (1993). The non-marine molluscs of the Cape Range peninsula, Western Australia. In: Humphreys, W.E. (ed.) The Biogeography of Cape Range, Western Australia. Western Australian Museum Supplement 45: 87-107.

Smith, B.J. (1984). Regional endemism of the south-eastern Australian land mollusc fauna. In: Solem, A. and Bruggen, A.C. (eds.) World-wide snails: biogeographical studies on non-marine Mollusca. Backhuys Publishers: Leiden.

Smith, B. and Stanisic, J. (1998). Pulmonata Introduction. In: Beesley, P.L., Ross, G.J.B. and Wells, A. (eds.) Mollusca: The Southern Synthesis: Fauna of Australia, Part A. CSIRO Publishing: Melbourne.

Smith, E.A. (1894). On the land-shells of Western Australia. Proceedings of the Malacological Society of London 1: 84-99.

Solem, A. (1988). Non-camaenid land snails of the Kimberley and Northern Territory, Australia I. Systematics, affinities and ranges. Invertebrate Systematics 4: 455-604.

Solem, A. (1993). Camaenid Land Snails from Western and Central Australia (Mollusca: Pulmonata: Camaenidae): VI. Taxa from the Red Centre. Records of the Western Australian Museum Supplement 43: 1-1459.

Solem, A. (1997). Camaenid land snails from western and central Australia (Mollusca: Pulmonata: Camaenidae). VII. Taxa from Dampierland through the Nullarbor. Records of the Western Australian Museum Supplement 50: 1-1906.

Solem, A. (1998). Family Bulimulidae. In: Beesley, P.L., Ross, G.J.B., Wells, A. (eds.) Mollusca: The Southern Synthesis: Fauna of Australia. Part A. CSIRO Publishing: Melbourne.

Sowerby II, S. (1845). Bulinus gunni. In: De Strzelecki, P.E. (ed.), Physical description of New South Wales and Van Diemen's Land: accompanied by a geological map, sections and diagrams, and figures of the organic remains. Longman, Brown, Green and Longmans: London.

Stanisic, J., Shea, M., Potter, D. and Griffiths, O. (2018). Australian Land Snails Volume 2. A field guide to southern, central and western species. Bioculture Press: Mauritius.

Tate, R. (1894). Brief diagnoses of Mollusca from Central Australia. Transactions of the Royal Society of South Australia 18: 191-194.

Thiele, J. (1930). Gastropoda und Bivalvia. In: Michaelsen, W. and Hartmayer, R. (eds.) Die Fauna Südwest-Australiens. Ergebnisse der Hamburger Südwest-Australischen Forschungsreise 1905. Gustav Fischer: Jena.

van der Geer, A.A.E. and Dermitzakis, M.D. (2013). Caves And Fossils: Palaeontology In Greek Caves And Fissures. In: Mavridis, F. and Jensen, J. T. (eds.) Stable Places and Changing Perceptions: Cave Archaeology in Greece. Archaeopress: Oxford.

Whisson, C. and Breure, A. (2016). A new species of Bothriembryon (Mollusca, Gastropoda, Bothriembryontidae) from south-eastern Western Australia. ZooKeys 581: 127-140.

Whisson, C. and Kirkendale, L. (2017). The presumed extinct Bothriembryon whitleyi Iredale, 1939 remains elusive. The Malacological Society of Australasia Newsletter 163: 1-6.

Wilson, B. (2008). Terrestrial Gastropods of Faure Island. Records of the Western Australian Museum Supplement 75: 21-24. doi: 10.18195/issn.0313-122x.75.2008.021-024.

Zilch, A. (1959-1960). Gastropoda 2. Euthyneura. In: Schindewolf, O. (ed.) Handbuch der Paläozoologie. Borntraeger: Berlin.

MANUSCRIPT RECEIVED 4 MAY 2019; ACCEPTED 8 AUGUST 2019. 